\title{
MINORITY EDUCATIONAL INSTITUTIONS IN INDIA - AN ANALYSIS
}

\author{
Yashraj Sharma
}

The Shri Ram School, Aravali.

DOI: 10.46609/IJSSER.2020.v05i01.002 URL: https://doi.org/10.46609/IJSSER.2020.v05i01.002

\section{ABSTRACT}

This paper aims at studying the foundation, organization and administration of Minority Educational Institutions in India, primarily focusing on Religious Minority Institutions. It analyses the working of such Institutions in India on a grassroot level and discusses certain conditions when the State intervenes in the functioning of these Minority run bodies. In order to critically analyse the National Commission on Minority Educational Institutions (NCMEI) Act, it interprets Judicial Pronouncements and Decisions of Indian Courts and various Constitutional Provisions. This document gives an Introduction into the foundation of these Institutions and the process for the same. It goes on to discuss the National Commission on Minority Educational Institutions Act at length, and analyses the composition of the NCMEI as a problematic area of the Act, and discusses various repercussions of this provision.

Keywords: Educational Policy, Minority Educational Institutions, National Commission on Minority Educational Institutions (NCMEI).

\section{INTRODUCTION}

Since India gained independence in 1947, Minorities have been at the helm of Indian Polity and the political decision-making process as they have diverse needs which must be taken into consideration during policy making. The education of these minorities has been of utmost importance of various governments in the past, and Article 30 of the Indian Constitution has empowered Minorities to establish and administer their own Educational Institutions. ${ }^{1}$

It reads:

"30. (1) All minorities, whether based on religion or language, shall have the right to establish and administer educational institutions of their choice."

${ }^{1}$ (Constitution) - Article 30(1) of IC 
International Journal of Social Science and Economic Research

ISSN: $2455-8834$

Volume: 05, Issue: 01 "January 2020"

This article makes it a fundamental right for the establishment of Minority Educational Institutions by the prohibition of its violation and divides minorities into two segments: Linguistic and Religious; however, this study primarily seeks to examine Religious Educational Institutions. Under the Constitution of India, the term 'minority' has not been defined. Nevertheless, the T.M.A Pai Foundation vs. State of Karnataka Case ${ }^{2}$ before the Supreme Court, which was referred to in the context of MEIs, declared that a minority is determinable only according to the demography of that particular state, and not the population of the Country as a whole. Therefore, Sikhism would cease to be a minority in Punjab and Islam in Jammu \& Kashmir; however, these would be minorities in Kerala as the majority of constituents of these states to do not practice Sikhism or Islam. This quantifies a Minority to largely be a State-wise construct, differing from state to state. Due to the very pluralistic nature of Indian Society, there are large variations in the definition of a Minority. This is a major characteristic that is further recalled later on in the paper.

Minority Educational Institutions have been defined through Section $2(\mathrm{~g})^{3}$ of the National Commission on Minority Educational Institutions Act of 2004, the central statute that governs these Institutions. It reads:

“2(g): Minority Educational Institution means a college or institution (other than a University) established or maintained by a person or group of persons from amongst the minorities"

The primary condition that any Institution must qualify is whether or not it is established by a member of a Minority. Criteria for minority educational institutions, as determined from Article 30 \& pronouncements of the Supreme Court would be:

1) The Institution established by a member/members of the minority,

2) The Institution is established for the benefit of the minority community,

3) The Institution in question must be administered by that minority community,

4) The Institution must reserve a minimum of $30 \%$ of all seats for the minority in question,

5) The Institution must not reserve more than $50 \%$ of its seats for members of that particular community.

\section{Determination of Minority Status}

The main determinant of Minority Status of any Institution is the National Commission on Minority Educational Institutions, which was established under the aforementioned Act of 2004.

${ }^{2}$ Supreme Court of India; T.M.A Pai Foundation vs. State of Karnataka(AIR2003SC355)

${ }^{3}$ NCMEI Act of 2004; https://mhrd.gov.in/sites/upload_files/mhrd/files/upload_document/NCMEIAct2004.pdf. 
International Journal of Social Science and Economic Research

ISSN: $2455-8834$

Volume: 05, Issue: 01 "January 2020"

The Commission takes into consideration particular cases and reviews relevant facts and documents regarding the Institutions, after which, through a careful analysis of pre-existing rules and laws, it declares said Institution as an MEI. The procedure follows a conventional mechanism employed by this Commission. First, a society or trust must be formed under the Societies Registration Act or Public Trust Act. A copy of the Trust Deed, Memorandum of Association, Rules \& Regulation/Byelaws with all amendments should be provided to the NCMEI as evidence. The Institution must then approach the State Government for Recognition as a MSC. Now, if the Institution's application is rejected or is pending for a long period of time, about 6 months from the date of filing the application, the Institution can approach the NCMEI. They must then approach the Authority under the state and only then move to the central commission. If the Institution in question satisfies all of the aforementioned criteria, the Commission would deem it to be a Minority Educational Institution.

The NCMEI Act and a recent judgement of the Supreme Court declares that the NCMEI has the power to grant minority status of any MEI. NCMEI has a wide scope and powers; and the following sections discuss it in detail, along with certain points of dissent and opposition to its mandate and composition.

\section{Judicial Decisions and Pronouncements}

This section critically analyses certain key judgements \& case law regarding minority educational institutions. It is important to note that a large number of provisions, rights and safeguards have been evolved through these judgements.

The Supreme Court, through its St. Xavier's vs. State of Gujarat Judgement ${ }^{4}$, pronounced that Article 30(1) elucidates that minorities are not prohibited from establishing and administering Educational Institutions in India. Minorities are protected under this Article in order to strengthen the integrity \& unity in India.

In Re: Kerala Education Bill ${ }^{5}$, the Supreme Court ruled that a minority is on that is numerically less than $50 \%$ according to the demographics of that state.

The SC also ruled in SK Patro vs. State of Bihar ${ }^{6}$ that protection under Article 30 extends only to minorities residing in India, and not foreigners.

${ }^{4}$ The Ahmedabad St.Xaviers vs. State of Gujarat. - https://indiankanoon.org/doc/703393/

5 Re: The Kerala Education Bill, ... vs Unknown on 22 May, 1958 - https://www.latestlaws.com/latestcaselaw/1958/march/1958-latest-caselaw-20-sc/

${ }^{6}$ Bishop S.K Patro vs. Bihar - https://indiankanoon.org/doc/1045854/ 
International Journal of Social Science and Economic Research

ISSN: 2455-8834

Volume: 05, Issue: 01 "January 2020"

In Azeez Basha vs. Union of India', it was pronounced that 'establish' \& 'administer' must be read conjunctively. Therefore, two major criteria are whether they are established by a Minority Community and whether the Administration of the MEI is vested in that Community.

The powers and abilities of these MEIs were established under the T.M.A Pai Foundation vs. State of Karnataka ${ }^{8}$ Judgement, through which the SC stated that the following were powers of these MEIs:

1) Admit Students

2) Set up a reasonable fee structure

3) Constitute a governing body

4) To appoint staff

5) Take action on the recklessness of their staff.

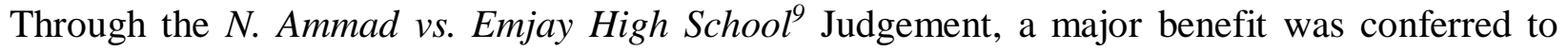
these MEIs: a Minority Educational Institution continues to be so even if the Government has not declared it as such. The Government merely recognizes the factual position and legal nature of the Institution.

Through the T.K.V.T.S.S \& Charitable Trust vs. State of Tamil Nadu ${ }^{10}$ judgement, the SC stated that the minority status of an MEI cannot be conferred for a particular period and renewed like a driver's license. It can only be changed and reviewed when there is a fundamental change in circumstances or a suppression of material fact.

A major landmark judgement which must be noted is: the Islamic Academy of Education vs. State of Karnataka ${ }^{11}$. It stated that there can be no rigid fee structure and the MEI can extract a certain surplus for growth and development; however, no capitation fee or profiteering can be done. It also ruled that Non-Minority Educational Institutes do indeed have the same rights as

\footnotetext{
${ }^{7}$ S. Azeez Basha And Anr vs Union Of India on 20 October, 1967 - https://indiankanoon.org/doc/1801897/.

${ }^{8}$ TMA Pai Foundation Case - http://nja.nic.in/P-950_Reading_Material_5-NOV-15/5.\%20T.M.A.\%20Pai.pdf.

${ }^{9}$ N. Ammad vs The Manager, Emjay High School - https://indiankanoon.org/doc/146760/.
}

10 Thirumuruga Kirupananda ... vs State Of Tamil Nadu \& Ors on 12 February, $1996 \quad-$ https://indiankanoon.org/doc/1537982/

$11 \quad$ Islamic Academy Case

http://righttoeducation.in/sites/default/files/W.P.\%20\%28C\%29\%20No.\%20317\%20of\%201993.PDF. 
International Journal of Social Science and Economic Research

ISSN: 2455-8834

Volume: 05, Issue: 01 "January 2020"

MEIs, although Non-MEIs do not have any protection under Article 30. Special rights under Article 30(1) does give MEIs some advantages.

Through the T.M.A Pai Foundation vs. State of Karnataka ruling pronounced that no Reservation Policy of the State can be applied to any unaided MEI or unaided Non-MEI. Moreover, even aided MEIs are not bound by Reservation Polices. This judgement also stated that Unaided MEIs cannot have any regulation of their admission or administration. They are free to fill all their seats by students of their Minorities, if they wish to. Any MEI cannot be denied affiliation with any State, Board or University on the basis of their minority status; however, the urgency of affiliation leads to certain regulations as these MEIs would be required to follow certain conditions to ensure the excellence of education and merit.

\section{National Commission for Minority Educational Institutions}

The National Commission for Minority Educational Institutions was established by the NCMEI Act, 2004, to safeguard minority institutions and their rights. It has a variety of powers and functions, under the provisions of the NCMEI Act and is a major governmental body which intervenes in the affairs of MEIs. It consists of a chairman, who must be a retired High Court Judge of a Minority and three other such High Court Judges as members. All members of the NCMEI must be from Minority Community. Legally and practically, it is a quasi-judicial body.

Functions under Chapter IV ${ }^{12}$ :

1) To advise the Government on any question referred to it

2) To Enquire on any petition presented to it by any minority institution for a violation of their rights

3) To Intervene in any proceeding involving any violation of their rights and grant leave to any court

4) Review constitutional measures \& specify measures to preserve minority status

5) To do any act necessary for the attainment of the objects of the commission.

Powers under Chapter V ${ }^{13}$ :

1) Whenever a dispute arises regarding the affiliation of an MEI to a University, the decision of the NCMEI is final and binding. This aspect proves to be problematic as it may lead to a one sided decision on a body which anyway favours MEIs.

\footnotetext{
${ }^{12}$ National Commission for Minority Educational Institutions Act 2004

${ }^{13}$ NCMEI Act, 2005 Amendment
} 


\section{International Journal of Social Science and Economic Research}

ISSN: $2455-8834$

Volume: 05, Issue: 01 "January 2020"

2) Has the powers of a civil court, in which the commission can try someone on oath, inspect cases and accept affidavits

3) Every proceeding of the NCMEI is a judicial proceeding

4) Has the power to cancel the minority status.

\section{Composition of the NCMEI: a Problematic Provision}

A problematic area of the Commission and the Act is that only members of a minority can be members of the NCMEI. As defined and established earlier, these minorities include: Muslims, Sikhs, Buddhists, Christians and Parsis ${ }^{14}$. In some small capacity, this provision of the Act legitimize the notion that a meritorious and abled Hindu / any other majority Judge is unfit to sit in the NCMEI just because they belong to the majority. Thus, a major question that arises is: Is it principally and constitutionally correct to exclude persons from a majority on an unfound presumption of their bias. The rationale provided by the Central Government on such a provision resides on the basis that this provision would boost minority representation within the body. As judges from the same minorities in question before the court would be members, they would aptly be able to recognize and sympathize with the diverse needs of these Institutions. However, several issues stem from this provision.

On a fundamental level, this provision assumes that the definition of a minority remains constant throughout the country. It assumes that Muslims, Sikhs and Christians, inter alia, remain to be a minority in each and every state of India. However, this is not the case. As established through the T.M.A Pai Foundation vs State of Karnataka, the Supreme Court established that a minority depends on the demographics of that particular state. Moreover, the Re: Kerala Education Bill established that a minority is one which is numerically less than $50 \%$ of the demographic population of that state. Read conjunctively, these signify that: if any community is less than $50 \%$ of a particular state, it is a minority. Moreover, a majority of one state could in fact be in minority in another state. These precedents lay down a Minority to be a state-wise construct; an element which differs from state to state.

Thus, Hindus are in a minority in Jammu \& Kashmir and Punjab; where Islam and Sikhism are the majority religions. This signifies that a Hindu School could be quantified as an MEI in these states. Moreover, Muslim Schools would cease to be an MEI in Jammu \& Kashmir. Likewise is the case with Sikh Schools in Punjab. These are merely two examples of such cases, and in the pluralistic Indian society, various such special circumstances exist. This causes the provision of the NCMEI Act to act to be paradoxical in nature. If this provision aims at maximising minority

\footnotetext{
${ }^{14}$ Re: Kerala Education Bill Case.
} 


\section{International Journal of Social Science and Economic Research}

ISSN: $2455-8834$

Volume: 05, Issue: 01 "January 2020"

representation in the Commission, it would fail to aptly represent the Hindu Institutions in Punjab, Jammu \& Kashmir and Assam.

On a similar tangent, one could argue that this provision is a classic example of a natural justice violation. Before the NCMEI, there are various cases in which disputes relating to the affiliation of an MEI to a Central University, inter alia, are taken up. By virtue of all members of this Commission being a member of a minority, there is a great potentiality of a bias. Moreover, this Commission acts as a de-facto civil court, with power to make certain binding decisions on parties. Therefore, in a fair and equitable system of Justice, a court should be completely fair and consist of judges devoid of even a miniscule potential of a bias.

Moreover, this provision also prevents certain meritorious judges from being a part of this Commission. Due to the fact that only a member of a minority can be a part of this Commission, on certain occasions, abled Hindu Judges must be passed over for the seat. This limits the level of meritocracy prevalent in this body.

A simple Policy Recommendation that effectively tackles this issue is to have ad-hoc judges be a part of this Commission. The current number of judges can be appointed on merit selection basis, whereas, ad-hoc judges (who are a part of all minority communities) can be part of all proceedings. Moreover, an ad-hoc judge from that particular Community can also sit in when the Commission in discussing a case of that particular minority. Not only would this move ensure that meritorious judges can adequately take part in committee proceedings, but also ensure that the specific needs of the community in question are addressed suitably, and no bias prevails.

\section{Possible Government Interventions while administering MEIs}

This section draws conclusions and links from various statutes and aforementioned judicial pronouncements to portray potential areas and conditions wherein the State of Central government has the power or authority to intervene in the conduct of these Minority Educational Institutions.

A major point of intervention is while granting in-aid; which is granted only after inspection is conducted \& there is a satisfactory report on the Infrastructure, Libraries and Buildings of the school. Aid usually covers about $95 \%$ of the teaching staff's salaries and a large amount of these Institutions rely heavily on aid from the Central or State Governments.

The National Commission of Minority Educational Institutions also has the final say in disputes regarding affiliation of the MEIs to a Central University. Moreover, As established in St. Xavier's vs. the State of Gujarat, the State can regulate the service conditions of employees of 


\section{International Journal of Social Science and Economic Research}

ISSN: $2455-8834$

Volume: 05, Issue: 01 "January 2020"

certain institutions. Any general law regarding service conditions of Educational Institutions will also apply to the MEIs.

The NCMEI and the Central Government also has the right to Cancel the Minority Status of these Institutions. Legal Schemes for monitoring admissions procedures \& fee fixation do not violate the rights of Minorities under Article 30(1).[PA Inamdar Case]

If the State Government does not grant Minority Status, or takes more than 6 Months to do so, the MEI can apply to the NCMEI for granting of this status. Moreover, The State can provide a Common Entrance Test (CET).

\section{CONCLUSION}

This paper aimed at analysing the structure of the functioning of Minority Educational Institutions, and various factors that go into their governance and administration. The paper largely focuses on the NCMEI Act and the powers vested to this body. At highlights the composition of this Commission to be problematic and paradoxical as it assumes that the definition of a Minority remains constant throughout India, and how this provision undermines principles of Natural Justice. It makes certain policy recommendations for revamping this Commission, by the provision of ad-hoc judges. It focuses its study on conditions and instances in which the Government intervenes in the administration of these MEIs and statutes regarding the same.

\section{About the Author}

Yashraj Sharma is a student studying in the Shri Ram School Aravali, in New Delhi. He is an avid academic writer and researcher, working primarily on projects regarding Public Policy, International Relations and Economics. He has worked with the Center for Civil Society (CCS) - a leading think tank in New Delhi - on the Educational Policies of India. Having worked with the Ministry of Health and Family Welfare in India, and the Central Square Foundation (CSF) on bettering the Quality of Education in Indian Public and Private Schools, he is specifically concerned about the Social Inequalities caused due to a lack of adequate education amongst the poor and illiterate. He is an active writer and researches about the future of Indian Foreign Relations. 